\title{
El libro infantil \\ Experiencias de creación y mundos posibles de la lectura en voz alta ${ }^{1}$
}

\author{
Galia Ospina Villalba \\ Universidad de Bogotá Jorge Tadeo Lozano \\ Colombia
}

$\mathrm{E}$ ste libro tiene su origen en la experiencia de lectura compartida en el contexto de los talleres literarios que coordino en la Fundación Universidad de Bogotá Jorge Tadeo Lozano, y en la experiencia de lectura con niños en la Biblioteca Pública El Tunal y la Biblioteca Pública Servitá.

Empecé a deshilvanar la escritura del texto rescatando mis lecturas de infancia y evocando el espacio de los recuerdos, que se tejen con los otros y el mundo. El libro abre la posibilidad de ser también un puente entre el mediador y los niños y jóvenes. Son tres aristas fundamentales del triángulo para mantener la coherencia y la estructura de la presente obra. La narración busca a su vez tejer diferentes voces y aspectos conceptuales con un tono testimonial, que no pierda de vista el desafiante equilibrio entre la experiencia, la reflexión a partir de lo vivido alrededor del centro solar de los libros, la lectura, y la relevancia del mediador en contextos pedagógicos.

La escritura se convierte en un viaje marcado por las voces que se han inscrito en mi libro interior para reconfigurarme en el mundo de la intersubjetividad.

El material ha sido organizado por capítulos para darle un orden lógico al planteamiento de los diversos temas abarcados. Sin embargo, cada parte puede ser leída como una unidad autónoma e independiente. El libro es un juego de reenvíos y reflejos entre los diferentes elementos que lo conforman como un tejido.

El primer capítulo expone una reflexión autobiográfica acerca de la primera escena de la lectura y de su poder para construir un lugar que se expande de acuerdo con el ejercicio de nuestra memoria e imaginación. Para definir los contornos de una lectura íntegra, recurrí al lúcido ensayo de Evelio Cabrejo Parra (2003) sobre "el libro interno o psíquico", "el libro de la intersubjetividad" y "el libro del mundo", que vuelve a unir las tres aristas del triángulo en el acto de la lectura en forma paralela a los conceptos fundamentales de la tradición estética expuestos por Jauss. Desde este enfoque se pretende realizar una aproximación a la 
lectura como un acto de trasgresión necesario para ensanchar fronteras y hacer catarsis en medio de situaciones conflictivas y difíciles. Este concepto, inspirado en la lectura de Michèle Petit (2001), se correlaciona con la experiencia de lectura compartida con el libro Donde viven los monstruos, de Maurice Sendak (2005). A partir del emblemático álbum se profundiza en el concepto del mediador de lectura.

El segundo capítulo ofrece una breve panorámica del libro álbum, que incluye una aproximación conceptual, un contexto histórico, un análisis de los paratextos internos y externos, y algunos de los autores más relevantes del género para redimensionarlos a la luz de la experiencia de lectura compartida con niños en las bibliotecas públicas. Con el fin de rememorar esta experiencia fue esencial rescatar los diarios de campo que escribí después de cada sesión de lectura en familia. También se encuentra una reflexión acerca del lugar que ocupa la lectura en los jóvenes universitarios desde el reconocimiento de sus escrituras y recuerdos de infancia.

El tercer capítulo rescata la pedagogía por proyectos desde la experiencia de generar una motivación hacia el proceso creativo de la maqueta de un libro álbum con los jóvenes universitarios. Este género permite una revolución cognitiva al elaborar una sinergia entre palabras e imágenes, que trasciende el terreno de lo obvio e inmediato para alcanzar la complejidad de la narración visual con un sentido de evocación y sugerencia. Se destaca también la superación del marco del aula para consolidar una exposición colectiva con los resultados del taller literario: Una aproximación al libro ilustrado, que tuvo lugar en la Biblioteca-Auditorio Fabio Lozano de la Fundación Universidad de Bogotá Jorge Tadeo Lozano. El evento se constituyó en un primer acercamiento entre los estudiantes y algunos maestros de diversas disciplinas y representantes de editoriales infantiles y juveniles.

Un cuarto apartado reflexiona sobre la puesta en escena de la lectura en biblioteca y resalta los rituales de lectura, el contacto visual, las modulaciones de la voz y los vínculos afectivos. Material rescatado a partir de diarios de campo que subrayan la experiencia de la mediación de la lectura con libros álbumes y otras lecturas compartidas con niños, niñas y familias. Cuando leí para niños en bibliotecas públicas, sentía que los abrazaba. Dejaba los libros en el centro del tapete y nos sentábamos en círculo para volver al ritual del fuego. Kafka decía que los libros derriten los enormes icebergs que llevamos dentro. Son fuego puro. Compartir la lectura en voz alta es regresar a la primera casa del fuego.

Este trabajo reúne entrevistas a estudiantes y a la investigadora, docente y bibliotecaria escolar María Clemencia Venegas; reseñas de libros álbumes, escritos y trabajos de los estudiantes de los talleres literarios que se hallaban dispersos y sin confederación en el brumoso paisaje de los recuerdos. El hilo conductor de todo el libro viene dado por el tono del testimonio, la significación del libro álbum y las lecturas compartidas que se irradian a lo largo de toda la obra como las ramificaciones de un árbol generoso.

Espero que este libro pueda ser de utilidad para los promotores de lectura, los bibliotecarios, las familias, los educadores y todos aquellos que 
buscan en la lectura un espacio íntimo que nos ayuda a conocernos mejor. Sé que otros lectores sabrán habitar mi voz. Y entonces mi limitado "yo" se volverá coro de voces, multiplicidad. Ya no será mi palabra, mi experiencia individual. Otros se leerán en estas líneas que ya no serán mías.

Que las palabras de este libro les rindan un homenaje a los bibliotecarios que construyen nación con una red de libros encantados, a las familias, a los educadores, a los críticos e investigadores, a los ilustradores y a los editores que hacen posible que el libro continúe siendo una tríada mágica.

Me gustaría cerrar esta breve introducción con las palabras del crítico e investigador literario venezolano $\mathrm{Fa}$ nuel Hanán Díaz:

Pienso que una imagen se conecta con el subconsciente del lector [...] Así de potente y atómica puede ser la repercusión que una imagen puede tener en la persona que la mira. No sólo porque puede dejar una huella en su almacén particular, sino porque recupera de su memoria fragmentada otras piezas que a veces ni siquiera sabe que tiene allí, bien sean arquetipos que atesora biogenéticamente, recuerdos u otras imáge- nes que forman parte de esa ineludible ley de la asociación libre. Lo cierto es que, a pesar de que podemos realizar una lectura superficial, a pesar de que toda imagen admite por lo menos esa primera capa, también ella debería permitirnos explorar esas segundas y terceras capas de significación. Precisamente las imágenes de calidad pueden lograr eso. (Díaz, 2007, p. 171).

Me he especializado en la coordinación y realización de talleres de creación que involucran a la persona humana. Mi corriente pedagógica es el Personalismo que integra la sensibilidad del diálogo y la relación amorosa con los otros. Trabajo actualmente en la Universidad de Bogotá Jorge Tadeo Lozano en un taller literario basado en la escritura de viajes y en otro dirigido a artistas. Lucho en contra de la corriente en aulas numerosas, pero para el amor no hay nada imposible. La palabra crea mundos y cuando proviene de la fértil tierra del corazón siempre deja huella.

\section{Nota}

1 Coedición: Pontificia Universidad Javeriana (Bogotá) y La Silueta, 2005. 
